Indo. J. Chem. Res., 2018, 5(2), 53-57

\title{
PENGARUH PEMANASAN BASAH DENGAN AUTOKLAF TERHADAP AKTIFITAS SENYAWA TOXALBUMIN PADA BIJI KEMIRI (Aleurites moluccana (L.) Willd)
}

\author{
Effect of Moist Heating Using Autoclav to Toxalbumine Activities in Candlenut \\ (Aleurites moluccana (L.) Willd)
}

\author{
Mamang $^{1 *}$, Mariyati Bilang ${ }^{1}$, Salengke ${ }^{2}$ \\ ${ }^{1}$ Department of Food Science and Technology Faculty of Agriculture, Hasanuddin University - Indonesia \\ ${ }^{2}$ Department of Agricultural Engineering Faculty of Agriculture, Hasanuddin University - Indonesia \\ *Corresponding author, e-mail: mamang.estepe@yahoo.com
}

Received: Nov. 2017 Published: Jan. 2018

\begin{abstract}
In addition to nutritional and non-nutritional content, candlenut also contains toxalbumin, toxic compound that can inhibit protein synthesis. This study aims to inhibit toxalbumin activity in candlenut through moist heating treatment, using hemagglutination method. Defatted candlenut powder was being treated under moist heating using autoclave at the temperature of $121^{\circ} \mathrm{C}$ for $5,10,15$ and 20 minutes followed by oven heating at the temperature of $70^{\circ} \mathrm{C}$ for 7 hours and control, continued by dry heating using oven at the temperature of $70^{\circ} \mathrm{C}$ for 7 hours and extraction using $0.15 \mathrm{M} \mathrm{NaCl}$ at room temperature then precipitated using ammonium suplhate $(60 \%)$ at room temperature for 4 hours. Supernatant was dialyzed with water and $0.15 \mathrm{M} \mathrm{NaCl}$ for 1 night each then being freeze dried. $1 \mathrm{~g}$ of obtained protein fraction was purified in Sephadex G-75 (10 cm x $1.0 \mathrm{~cm})$ column. Resulted extract was re-dried using freeze dryer for hemagglutination test towards $\mathrm{A}, \mathrm{B}, \mathrm{AB}$ and $\mathrm{O}$ blood types. The result shows that toxalbumin acitivities were inhibited by moist heating in autoclave at the temperature of $121^{\circ} \mathrm{C}$ for 10 minutes followed by drying in oven $70^{\circ} \mathrm{C}$ for 7 hours.
\end{abstract}

Keywords: Candlenut, moist heating, toxalbumin, hemagglutination.

\section{PENDAHULUAN}

Tanaman kemiri (Aleurites moluccana (L.) Willd) merupakan salah satu tanaman dari keluarga Euphorbiaceae (Lawrence, 1964) yang tersebar di daerah tropik dan subtropik (Purseglove, 1981). Di Indonesia sendiri, kemiri tersebar ke berbagai propinsi dan dapat tumbuh dengan baik. Kemiri mengandung zat gizi dan non gizi. Banyak peneliti telah membuktikan bahwa ketiga komponen ini memiliki arti besar bagi kesehatan. Kandungan zat gizi mikro yang terdapat dalam kemiri adalah protein, lemak dan karbohidrat. Mineral dominan yang terdapat dalam kemiri adalah kalium, fosfor, magnesium, dan kalsium. Dalam kemiri juga terkandung zat besi, seng, tembaga dan selenium dalam jumlah sedikit. Kandungan penting lainnya adalah vitamin, folat, serta fitosterol yang dapat merusak enzim pembentuk kolesterol dalam hati sehingga dapat menghambat pembentukan kolesterol. Protein pada biji kemiri terdiri dari asam amino essensial maupun non esensial, fungsi asam amino esensial antara lain untuk pertumbuhan karena asam amino terdapat di semua jaringan dan membentuk protein dan antibodi. Asam amino non esensial yang menonjol pada kemiri yaitu asam glutamate dan asam aspartat. Keberadaan asam glutamate yang memberikan rasa nikmat ketika kemiri digunakan sebagai bumbu dapur yang dapat menjadi pengganti penyedap masakan seperti MSG (Wiyono dan Poedji, 1993).

Selain mengandung komponen gizi dan non gizi, biji kemiri mengandung senyawa racun yaitu toxalbumin. Toxalbumin merupakan glikoprotein bersifat toksik yang dapat berpengaruh pada darah yang ditandai dengan adanya aglutinasi atau penggumpalan pada darah (Aregheore, et al, 1998). Toxalbumin adalah fitotoxin protein (racun yang diproduksi oleh tanaman) yang dapat menghambat sintesis protein. Senyawa ini menjadi salah satu faktor pembatas pemanfaatan kemiri didalam industri pangan. Sementara disatu sisi produksi buah kemiri yang melimpah merupakan potensi yang 
sangat besar untuk pegembangan industri pengolahan pangan, termasuk sebagai bahan substitusi kacang-kacangan seperti almond dan kacang mete pada industri pengolahan cokelat.

Toxalbumin merupakan racun yang terdapat secara alami dalam tanaman. Ricin merupakan salah satu senyawa toxalbumin yang terdapat pada biji jarak (Ricinus communis) dan tanaman yang berasal dari family Euphorbiaceae. Ricin adalah protein yang sangat berbahaya dan keras, racun ini dapat menimbulkan beberapa penyakit pada beberapa organ yang berbeda dan kemudian akan berakibat pada kematian (Saeidnia dan Abdollahi, 2013). Aktifitas hemaglutinasi pada glikoprotein lectin yang diekstrak Cissus popluena dalam darah terhambat dengan kenaikan konsentrasi glukosa dan fruktosa (Ayowinka and Dada, 2011)

Mekanisme kerja ricin yang merupakan senyawa glikoprotein pada tanaman jarak melibatkan molekul yang terdiri dari rantai-A (32 Kda) yang bersifat netral terikat dengan rantai-B (34 Kda) yang bersifat asam. Subunit-B mengikat glikoprotein pada permukaan sel epitel, sehingga memungkinkan subunit-A untuk masuk ke dalam sel melalui receptor-mediated endocytosis. Sub unit ini akan menginaktivasi RNA ribosom dengan cara mendepurinasi residu ribosom tertentu, sehingga menghambat sintesis protein (Lord et al., 1994 dalam Schep et al, 2009). 1 molekul risin dapat menginaktivasi 2000 ribosom per menit yang secara luar biasa dapat menyebabkan kematian sel (Schep et al., 2009). Pada manusia, $500 \mu \mathrm{g}$ ricin dapat menimbulkan kematian setelah $36-72$ jam (Anonim, 2010).

Racun toxalbumin pada biji kemiri dapat dihilangkan dengan perlakuan pemanasan sebelum mengkonsumsi biji kemiri. Masyarakat pada umumnya memberikan perlakuan pemanasan singkat seperti pembakaran ataupun penggorengan pada biji kemiri sebelum diolah menjadi bahan campuran makanan (Paimin, 1997). Dari uraian diatas maka perlu dilakukan penelitian untuk mengetahui pengaruh pemanasan terhadap aktivitas senyawa toxalbumin pada biji kemiri. Pada penelitian ini pemanasan yang dilakukan adalah pemanasan basah menggunakan autoklaf dengan variasi waktu.

\section{METODOLOGI}

\section{Bahan}

Bahan-bahan yang digunakan pada penelitian ini adalah, biji kemiri, aluminium foil, $\mathrm{NaCl}$, ammonium sulfate, PBS (Phospat Buffer Saline) $\mathrm{pH} 7.4, \mathrm{n}$-heksan, kloroform, dialysis sach $12 \mathrm{kDa}$, darah manusia golongan $\mathrm{A}, \mathrm{B}, \mathrm{AB}$ dan $\mathrm{O}$.

\section{Alat}

Alat-alat yang digunakan pada penelitian ini adalah autoklaf, timbangan analitik, oven, pipet volumetric $5 \mathrm{ml}$, sentrifuge, tabung eppendorph, gelas piala, labu ukur 50 dan $100 \mathrm{ml}$, mikropipet, well plate, erlenmeyer, magnetic stirrer, tabung reaksi, pipet volume, freeze dryer, alat press lemak.

\section{Perlakuan penelitian}

Perlakuan pada penelitian ini meliputi tanpa pemanasan sebagai kontrol (P0), pengeringan dalam oven $70{ }^{\circ} \mathrm{C}$ selama 7 jam (P1), pemanasan basah dengan autoklaf $121{ }^{\circ} \mathrm{C}$ selama 5 menit (P2), pemanasan basah dengan autoklaf $121{ }^{\circ} \mathrm{C}$ selama 10 menit $(\mathrm{P} 3)$, pemanasan basah dengan autoklaf $121{ }^{\circ} \mathrm{C}$ selama 15 menit (P4), pemanasan basah dengan autoklaf $121{ }^{\circ} \mathrm{C}$ selama 20 menit (P5). Untuk P2, P3, P4 dan P5 masing-masing dilanjutkan dengan pengeringan pada oven dengan suhu $70{ }^{\circ} \mathrm{C}$ selama 7 jam.

\section{Prosedur penelitian \\ Preparasi biji kemiri}

Sebanyak 0,1 gram ekstak kemiri ditambahkan dengan $10 \mathrm{ml}$ PBS, dihomogenisasi dengan kecepatan $2000 \mathrm{rpm}$ selama 5 menit atau 2 x 2,5 menit berturut-turut. Selama selang waktunya, sampel disimpan dalam es atau air es. Homogenat kemudian disentrifugasi pada $3500 \mathrm{~g}$ selama 10 menit. Supernatan diambil dan dimasukkan dalam tabung eppendorph. Disentrifugasi pada $9500 \mathrm{~g}$ selama 5 menit. Supernatan diambil dan digunakan sebagai untuk pengujian hemagglutinasi dengan beberapa serial pengenceran larutan PBS. Prosedur diatas dilakukan pada masing-masing biji kemiri hasil perlakuan.

\section{Preparasi sel darah merah}

Sebanyak $2 \mathrm{ml}$ darah dimasukkan kedalam tabung $15 \mathrm{ml}$ ditambahkan PBS sampai tanda batas, kemudian disentrifugasi pada $800 \mathrm{rpm}$ 
selama 10 menit. Supernatan dikeluarkan, pellet (sel darah merah) dicuci dengan menambahkan $12 \mathrm{ml}$ PBS, dicampurkan dengan membalikkan tabung, disentriugasi pada $800 \mathrm{rpm}$ selama 5 menit. Proses pencucian ini diulangi 2 kali. Supernatan setelah pencucian terakhir dikeluarkan, sel darah merah ditambahkan dengan PBS secukupnya sampai diperoleh $10 \%$ larutan sel darah merah. Kemudian dibuat 0,5\% larutan sel darah merah (SDMs) dalam PBS, yang akan digunakan pada tahap analisa selanjutnya. Prosedur diatas dilakukan pada masing-masing sampel darah (golongan A, B, $\mathrm{AB}$ dan $\mathrm{O})$.

\section{Pengujian hemaglutinasi}

Disiapkan microtiter plate 96-well. Kedalam setiap well (lubang) baris pertama diisi dengan $50 \mu \mathrm{l}$ PBS. Pada well pertama, ditambahkan $50 \mu \mathrm{l}$ ekstrak glikoprotein kemiri yang telah disiapkan sebelumnya, kemudian diencerkan menggunakan mikropipet dengan cara menghisap dan menekannya lalu dipindahkan $50 \mu \mathrm{l}$ ke well kedua. Dicampur dan diencerkan lagi kemudian pindahkan $50 \quad \mu \mathrm{l}$ ke well ketiga, diulangi pada well selanjutnya sampai pada well 12. Pada well 12 diambil dan dibuang $50 \mu \mathrm{l}$. Selanjutnya, kedalam masingmasing well ditambahkan $50 \mu 10.5 \%$ SDMs dalam PBS, digoyang selama 1 menit dan dibiarkan pada suhu kamar selama $30-60$ menit. Kemudian dilakukan pengamatan.

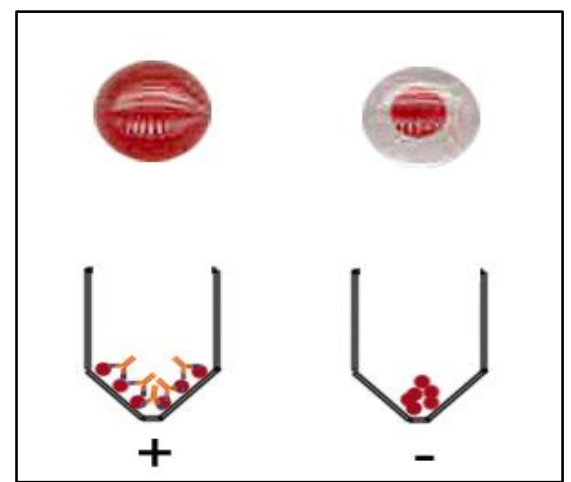

Gambar 1 Hasil uji hemaglutinasi

Hasil uji hemaglutinasi dinyatakan positif jika pada dasar microtiter plate tampak presipitat halus seperti pasir yang berarti terjadi aglutinasi (penggumpulan) sel darah merah (Batson dalam Haryanto, dkk., 2012), sebagaimana terlihat pada Gambar 1.

\section{HASIL DAN PEMBAHASAN}

Uji hemaglutinasi merupakan suatu uji untuk mengetahui keberadaan antigen virus yang dapat mengaglutinasi sel darah merah. Pada penelitian ini uji hemaglutinasi dimaksudkan untuk mengetahui efektifitas perlakuan pemanasan basah terhadap keberadaan senyawa toxalbumin dengan melihat daya aglutinasi senyawa tersebut pada sel darah merah. Hasil uji hemaglutinasi ekstrak biji kemiri dari berbagai perlakuan pada sel darah merah $\mathrm{A}, \mathrm{B}, \mathrm{AB}$ dan $\mathrm{O}$ dapat dilihat pada masing-masing pada Gambar 2.

Berdasarkan Gambar 2, terlihat bahwa daya aglutinasi ekstrak biji kemiri pada sel darah merah golongan darah $\mathrm{A}$ dan $\mathrm{AB}$ mulai tidak terlihat pada pengenceran ke-7 (n7) perlakuan P3. Hal ini berarti perlakuan pemanasan basah dengan autoklaf pada suhu $121{ }^{\circ} \mathrm{C}$ selama 10 menit dan dilanjutkan dengan pengeringan pada oven suhu $70{ }^{\circ} \mathrm{C}$ selama 7 jam (P3) sudah mampu menghambat aktifitas senyawa toxalbumin pada biji kemiri. Hasil uji hemaglutinasi pada golongan darah $\mathrm{B}$, memperlihatkan bahwa pada pengenceran ke-8 (n8) perlakuan pemanasan basah dengan autoklaf pada suhu $121^{\circ} \mathrm{C}$ selama 10 menit dan dilanjutkan dengan pengeringan pada oven suhu $70{ }^{\circ} \mathrm{C}$ selama 7 jam (P3) tidak menunjukkan terjadinya aglutinasi sel darah merah, yang berarti bahwa perlakuan tersebut telah menghambat aktifitas senyawa toxalbumin pada biji kemiri.

Begitupun dengan hasil uji hemaglutinasi pada golongan darah $\mathrm{O}$, diketahui bahwa senyawa toxalbumin pada biji kemiri perlakuan pemanasan basah dengan autoklaf pada suhu $121{ }^{\circ} \mathrm{C}$ selama 10 menit dan dilanjutkan dengan pengeringan pada oven suhu $70{ }^{\circ} \mathrm{C}$ selama 7 jam (P3) pada pengenceran ke-6 (n6) sudah tidak aktif lagi. Hal ini ditandai dengan tidak terjadinya aglutinasi pada sel drah merah. 


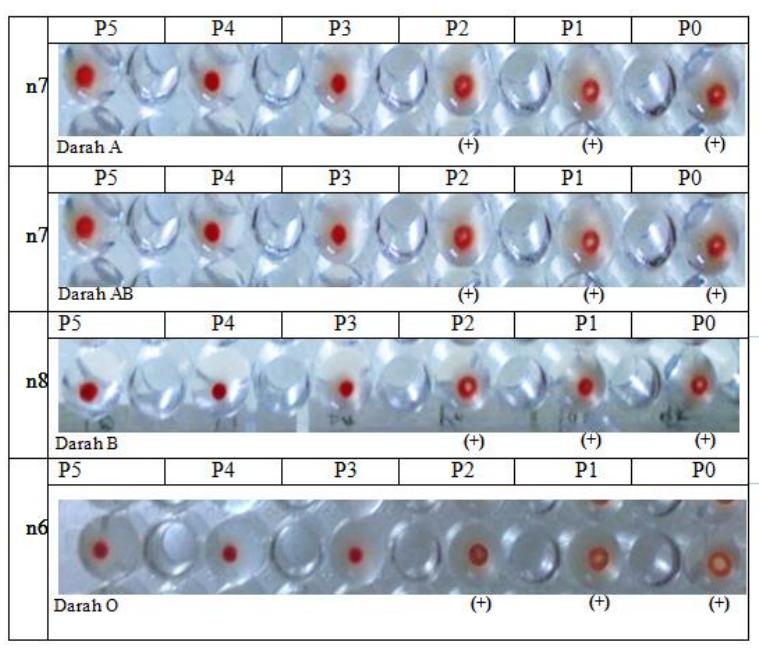

Keterangan :

PO : Kontrol (tanpa pemanasan)

$P 1$ : Tanpa pemanasan basah, pengeringan dalam oven $70^{\circ} \mathrm{C}, 7 \mathrm{jam}$

$P 2$ : Pemanasan basah dengan autoklaf $121^{\circ} \mathrm{C}, 5$ mnt dan pengeringan $\mathrm{dlm}$ oven $70^{\circ} \mathrm{C}, 7$ jam

$P 3$ : Pemanasan basah dengan autoklaf $121^{\circ} \mathrm{C}, 10 \mathrm{mnt}$ dan pengeringan $\mathrm{dlm}$ oven $70^{\circ} \mathrm{C}, 7$ jam

P4 : Pemanasan basah dengan autoklaf $121^{\circ} \mathrm{C}, 15 \mathrm{mnt}$ dan pengeringan dlm oven $70^{\circ} \mathrm{C}, 7 \mathrm{jam}$

P5 : Pemanasan basah dengan autoklaf $121^{\circ} \mathrm{C}, 20 \mathrm{mnt}$ dan pengeringan $\mathrm{dlm}$ oven $70^{\circ} \mathrm{C}, 7 \mathrm{jam}$

ni : Pengenceran ke- $i$

$(+) \cdot$ Teraslutinasi

Gambar 2 Hasil uji hemaglutinasi dari berbagai perlakuan pemanasan basah pada berbagai golongan darah

Hasil penelitian yang diperoleh sejalan dengan penelitian yang dilakukan oleh Situru M (2014), yang melaporkan bahwa senyawa toxalbumin pada biji kemiri sudah berkurang yang ditandai dengan sudah tidak terjadi lagi aglutinasi pada sel darah merah dengan pemanasan basah suhu $121{ }^{\circ} \mathrm{C}, 15$ menit kemudian pengeringan suhu $80{ }^{\circ} \mathrm{C}, 8$ jam, begitupun dengan penelitian Anggareni (2014) melaporkan bahwa hasil uji hemaglutinasi ekstrak biji kemiri yang telah dipanaskan pada suhu $121{ }^{\circ} \mathrm{C}, 15$ menit tidak menunjukkan aglutinasi. Aregheore et al (1998), melaporkan hasil uji hemaglutinasi lektin inaktif dengan pemanasan pada suhu $121{ }^{\circ} \mathrm{C}$ selama 10 - 40 menit. Lektin ini merupakan salah satu senyawa glikoprotein yang bersifat toksik yang terdapat pada tanaman jarak.

Dari hasil penelitian, diketahui bahwa aktifitas senyawa toxalbumin pada biji kemiri dengan konsentrasi yang rendah pada semua golongan darah $(\mathrm{A}, \mathrm{B}, \mathrm{AB}$ dan $\mathrm{O})$ sudah dapat dihambat dengan perlakuan pemanasan basah dengan autoklaf pada suhu $121{ }^{\circ} \mathrm{C}$ selama 10 menit dan dilanjutkan dengan pengeringan pada oven suhu $70{ }^{\circ} \mathrm{C}$ selama 7 jam (P3). Pada golongan darah $\mathrm{A}$ dan $\mathrm{B}$ sudah terhambat pada pengenceran ke-7, golongan darah $A B$ pada pengenceran ke-8 dan golongan darah $\mathrm{O}$ pada pengenceran ke- 6 .

Hasil penelitian juga menunjukkan bahwa jenis golongan darah tidak memberikan pengaruh terhadap aktifitas senyawa toxalbumin pada biji kemiri. Hal ini sesuai dengan hasil penelitian Ayowinka dan Dada (2011), bahwa aktivitas hemaglutinasi lectin (senyawa glikoprotein Cissus populnea) terhadap sel darah manusia tidak selektif terhadap jenis golongan darah.

Ikatan yang menghubungkan antara gula dan asam amino pada kebanyakan glikoprotein adalah ikatan hidrogen. Ikatan hidrogen sangat dipengaruhi oleh peningkatan suhu, dimana pada suhu tinggi ikatan hidrogen akan putus (Jaya dkk., 2016; Taufik 2011). Hal ini menyebabkan molekul gula dan asam amino akan terpisah sehingga kemampuan untuk mengaglutinasi darah akan hilang. Menurut Lord et al., 1994 dalam Schep et al., 2009, mekanisme kerja ricin yang merupakan senyawa glikoprotein pada tanaman jarak melibatkan molekul yang terdiri dari rantai-A (32 Kda) yang bersifat netral terikat dengan rantai-B (34 Kda) yang bersifat asam. Subunit-B mengikat glikoprotein pada permukaan sel epitel, sehingga memungkinkan subunit-A untuk masuk ke dalam sel melalui receptor-mediated endocytosis. Sub unit ini akan menginaktivasi RNA ribosom dengan cara mendepurinasi residu ribosom tertentu, sehingga menghambat sintesis protein.

\section{KESIMPULAN}

Aktivitas senyawa toxalbumin pada biji kemiri terhambat dengan pemanasan basah pada autoklaf suhu $121{ }^{\circ} \mathrm{C}$ selama 10 menit dilanjutkan dengan pengeringan dalam oven suhu $70{ }^{\circ} \mathrm{C}$ selama 7 jam dan tidak selektif terhadap jenis golongan darah.

\section{DAFTAR PUSTAKA}

Anggareni, A., 2014, Pengaruh Pemanasan Basah dan Pemanasan Kering terhadap Kadar Toxalbumin dan Mutu Biji Kemiri (Aleurites moluccana). Skripsi. Program Studi Ilmu dan Teknologi Pangan, Universitas Hasanuddin.

Anonim, 2015a, Ricin Toxin from Castor Bean Plant, Ricinus communis. Diakses 20 Mei 
2015.Available from: http://www.ansci. cornell.edu/plants/toxicagents/ricin. html.

Anonim, 2015b, Hemagglutination (HA) Assay Protocol. Diakses 20 Mei 2015. Available from : http://www.VIRAPUR.com

Aregheore, E.M., Makkar, H.P.S, Bekker, K., 1998, Assessment of Lectin Activity in A tonic and a Non-Tonic Variety of Jatropha curcas using Latex Agglutination and haemagglutination Methods and Inactivation of Lectin by Heat Treatments, $J$ Sci Food Agric. 1998, 77. 349-352.

Awoyinka, O.A., Dada, O.O., 2011, Partial Purification and Characterization Lectin from the Seeds of Cissus popluena. European Journal of Medicinal Plants. 1(4): 130-139, 2011.

Haryanto, A., Kristanti, B., Irianingsih, S.H., Yudianingtyas, D.W., 2012, Diagnosis Molekuler Virus Flu Burung-A Subtipe H5 Berdasarkan Amplifikasi Gen M dan H5 dengan Metode Onestep Simplex RT-PCR. Jurnal Veteriner. 13(2): 92-101.

Jaya, R.S., Ginting, S., Ridwansyah, 2016, Pengaruh Suhu Pemanasan dan Lama Penyimpanan Terhadap Perubahan Kualitas Nira Aren, Jurnal Rekayasa Pangan dan Pertanian, 4(1).

Lawrence, 1964, Taxonomi of Vascular Plants, New York: The MC Milan Co.

Paimin, F.R., 1997, Kemiri : Budidaya dan Prospek Bisnis, Penebar Swadaya. Jakarta.
Purseglove, J.W., 1981, Aleurites Moluccana Wild, Tripocal Crops Dicotyledons, Vol 1. The Print house (Pte) Ltd, Singapore L: 140-144.

Schep, L.J., Temple, W.A., Butt, G.A., Beasley, M.D., 2009, Ricin as a Weapon of Mass Terror-Separating Fact From Fiction, Environment International. 35 (2009) 12671271.

Situru, M. 2014, Studi Pengaruh Pemanasan Basah dan Pemanasan Kering Terhadap Kandungan Toxalbumin Pada Biji Kemiri (Aleurites mollucana). Skripsi. Program Studi Ilmu dan Teknologi Pangan, Universitas Hasanuddin, Makassar.

Taufik, M., 2011, Kajian Potensi Kulit Kaki Ayam Broiler sebagai Bahan Baku Gelatin dan Aplikasinya dalam Edible Film Antibakteri, Disertasi, Fakultas Peternakan Universitas Gadjah Mada, Yogyakarta

Wiyono, B., Poedji H., 1993, Pengaruh Perlakuan Pendahuluan Biji Kemiri Terhadap Rendemen dan Sifat Minyaknya, Jurnal Penelitian Hasil Hutan. 11(5) 173174. 